\title{
Kurort Health Walking Preferentially Decreases Higher Blood Pressure and Improves Mood
}

\author{
Shinya Minatoguchi, MD, PhD; Taro Minagawa, MD, PhD; Kazuhiko Nishigaki, MD, PhD; \\ Shinsuke Ojio, MD, PhD; Shinji Yasuda, MD, PhD; Kaori Osawa, BSc; \\ Munenori Sasaki, BSc; Masashi Ogawa, BSc; Tatehiro Marumo, BSc; Shin Takano, BSc
}

\begin{abstract}
Background: Kurort is a German term from the words kur (cure) and ort (area), and refers to improvements in patients' health in areas full of nature. We investigated the effect of kurort health walking in the 2 urban-style kurort health walking courses opened in Gifu City on systolic blood pressure (SBP), diastolic blood pressure (DBP), heart rate, and mood.

Methods and Results: The subjects were 454 people (136 males, 318 females; mean $[ \pm S D]$ age $61.7 \pm 9.9$ years) taking part in kurort health walking for the first time. SBP, DBP, and heart rate were measured before and after kurort health walking. Mood was assessed using a 10-item checklist after kurort health walking. Kurort health walking significantly decreased SBP and DBP and increased heart rate. The decrease in SBP was significantly greater in the SBP $\geq 140$ than $<140 \mathrm{mmHg}$ group, indicating that SBP before Kurort health walking was inversely correlated with the change in SBP. Similarly, the decrease in DBP was significantly greater in the DBP $\geq 90$ than $<90 \mathrm{mmHg}$ group, indicating that DBP before kurort health walking was also inversely correlated with the change in DBP. All 10 items on the mood assessment were significantly improved after kurort health walking.
\end{abstract}

Conclusions: Kurort health walking preferentially decreases higher blood pressure and improves mood.

Key Words: Diastolic blood pressure; Kurort health walking; Mood; Systolic blood pressure

H ypertension and mental health status (e.g., depression) have been reported to be associated with cardiovascular events. ${ }^{1-3}$ Therefore, it is important to control blood pressure and to maintain a healthy mental state to reduce the risk of cardiovascular events. Although antihypertensive drugs and antidepressants are useful in preventing hypertension and depression, respectively, some lifestyle modifications may also be effective. Kurort is a German term from the words kur (cure) and ort (area) and refers to improvements in patients' health in areas rich in nature, such as scenic hills, forests, rivers, hot springs, and areas with a good climate. ${ }^{4}$ In Japan, Japanesestyle kurort, based on the German kurort, has recently been developed and has become popular with the support of local governments and companies. Kurort health walking describes walking in a healthy area called kurort. On October 26, 2019, Gifu City opened 2 urban-style kurort health walking courses, the Mt. Kinka-Nagara River-Gifu Park course and the Mt. Dodogamine-Nagara River-Fureai Forest course, and has been encouraging citizens to participate in kurort health walking. These 2 courses are easily accessible to citizens. Because these 2 kurort health walking courses are rich in nature, well designed, and well maintained, walking such courses may have a good effect on physical and mental health, which are related to cardiovascular disease.

The aim of the present study was to investigate the effects of kurort health walking in the kurort health walking courses in Gifu City on systolic blood pressure (SBP), diastolic blood pressure (DBP), heart rate, and mood.

\section{Methods}

Participants in the kurort health walking program obtained information regarding the places, dates, and times for kurort health walking through the public relations magazines of Gifu City. The subjects in this study were 454 firsttime kurort health walking participants who used either of the 2 kurort walking courses in Gifu City between June 1, 2020 and May 30, 2021.

Because some people undertook kurort health walking several times, the total cumulative number of participants

Received July 27, 2021; revised manuscript received August 20, 2021; accepted September 2, 2021; J-STAGE Advance Publication released online October 6, 2021 Time for primary review: 15 days

Cardiology, Gifu Municipal Hospital, Gifu (S.M., K.N., S.O., S.Y., K.O.); Minagawa Clinic, Gifu (T. Minagawa); and Health Promotion Section, Gifu Municipal Office, Gifu (M.S., M.O., T. Marumo, S.T.), Japan

S.M. is a member of Circulation Reports' Editorial Team.

Mailing address: Shinya Minatoguchi, MD, PhD, Cardiology, Gifu Municipal Hospital, 7-1 Kashimacho, Gifu 500-8513, Japan. E-mail:minatos@gifu-u.ac.jp

All rights are reserved to the Japanese Circulation Society. For permissions, please e-mail: cr@j-circ.or.jp

ISSN-2434-0790 


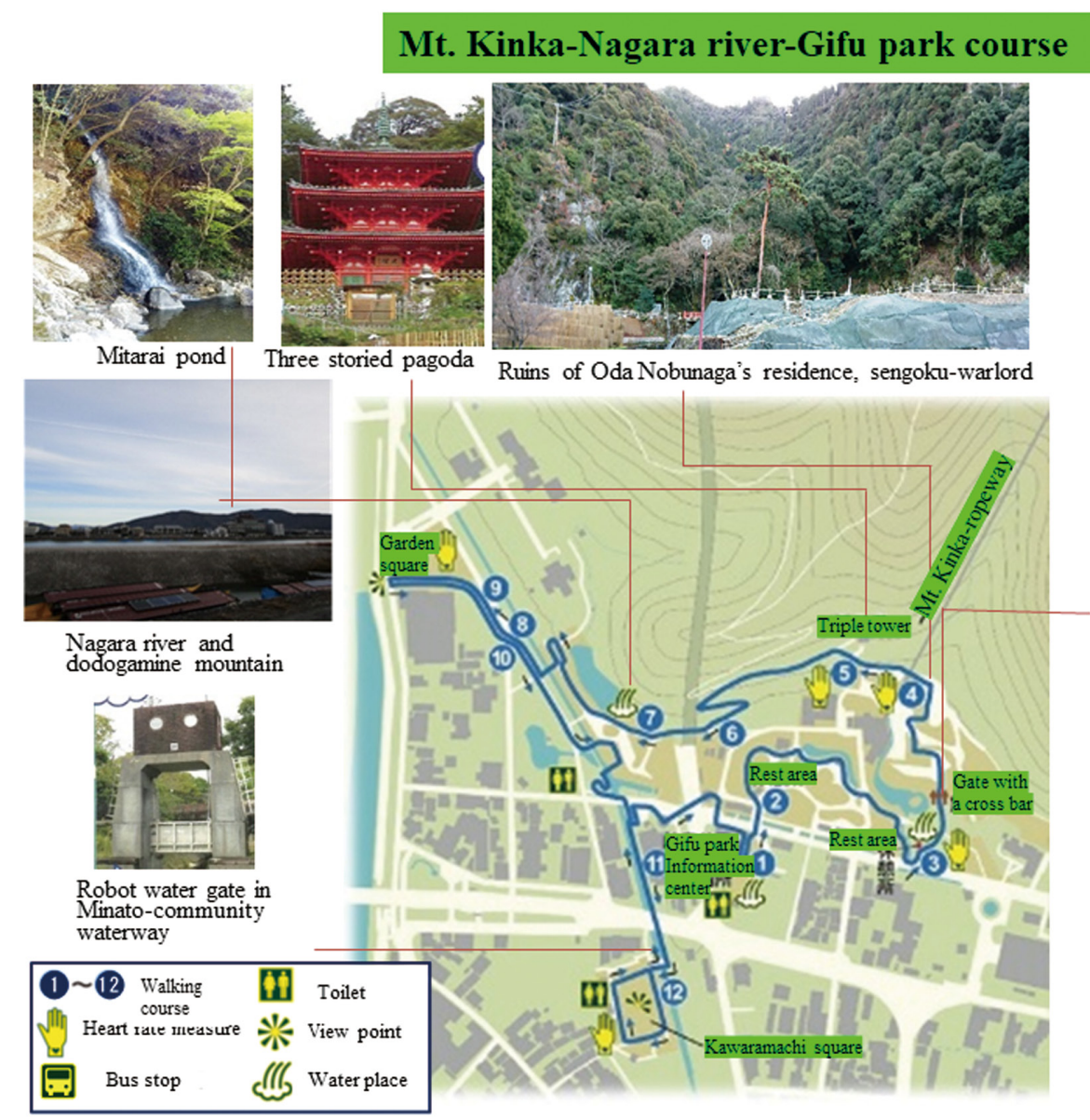

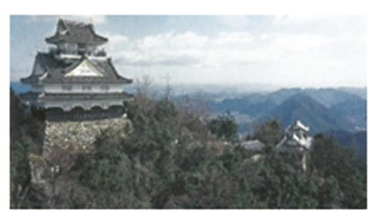

Gifu castle

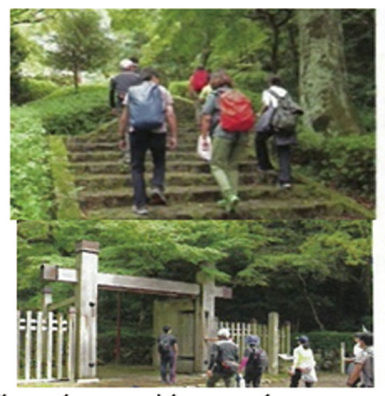

Through gate with a crossbar, step up the stairs reaches target heart rate

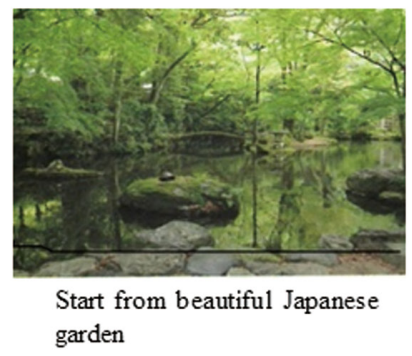

Figure 1. Mt. Kinka-Nagara River-Gifu Park course. This course is situated in the city center close to the Nagara River and extends to the foot of Mt. Kinka. This course is $2.3 \mathrm{~km}$ long and has an elevation of $30 \mathrm{~m}$.

in the program was 893 ; however, only those people walking the course for the first time were enrolled in the present study. All participants agreed to take part in the study and provided written informed consent before the study commenced. No one dropped out during the study.

Participants were asked to provide details regarding their age, sex, height, weight, presence of hypertension, dyslipidemia, and diabetes on a checklist before walking. SBP, DBP, and heart rate were measured using a wrist-type automatic sphygmomanometer, which is easy to use outdoors, before and after kurort health walking. After walking, participants were asked to complete a survey to evaluate changes in mood.

To ensure safety, participants with an SBP $>180 \mathrm{mmHg}$ and/or a DBP $>110 \mathrm{mmHg}$ are prohibited from kurort health walking, and kurort health walking is not performed in July and August because of the very hot climate in Gifu City in summer. Warming-up exercise before walking and cooling-down exercises after walking were performed under the direction of the health exercise instructors.

There are 2 courses for kurort health walking in Gifu City. The Mt. Kinka-Nagara River-Gifu Park course (Figure 1) is situated in the city center close to the Nagara River and extends to the foot of Mt. Kinka. This course is $2.3 \mathrm{~km}$ long and has an elevation of $30 \mathrm{~m}$. The Mt. DodogamineNagara River-Fureai Forest course (Figure 2) is situated in the northern area of the city and consists of a beautiful forest with many seasonal birds. This course is $3.2 \mathrm{~km}$ long and has an elevation of $80 \mathrm{~m}$.

To maintain target heart rate during walking, participants were asked to measure their heart rate at 5 points on the Mt. Kinka-Nagara River-Gifu Park course, and on 6 points on the Mt. Dodogamine-Nagara River-Fureai Forest course (Figures 1,2). Participants walked either course, accompanied by 2 health exercise instructors. The target heart rate during walking was defined as (160-age) beats/min. If the heart rate increased beyond the target heart rate, participants were asked to slow the pace of walking so that heart rate was maintained under the target. Because the exercise level was maintained under the anaerobic threshold, it was considered safe for cardiac patients. 5

This study was approved by the Ethics Committee of Gifu Municipal Hospital (Approval no. 634) and conformed with the principles outlined in the Declaration of Helsinki (Br Med J 1964; ii: 177). This study was registered with the University Hospital Medical Information Network (UMIN) Clinical Trials Registry (ID: UMIN000041617). 


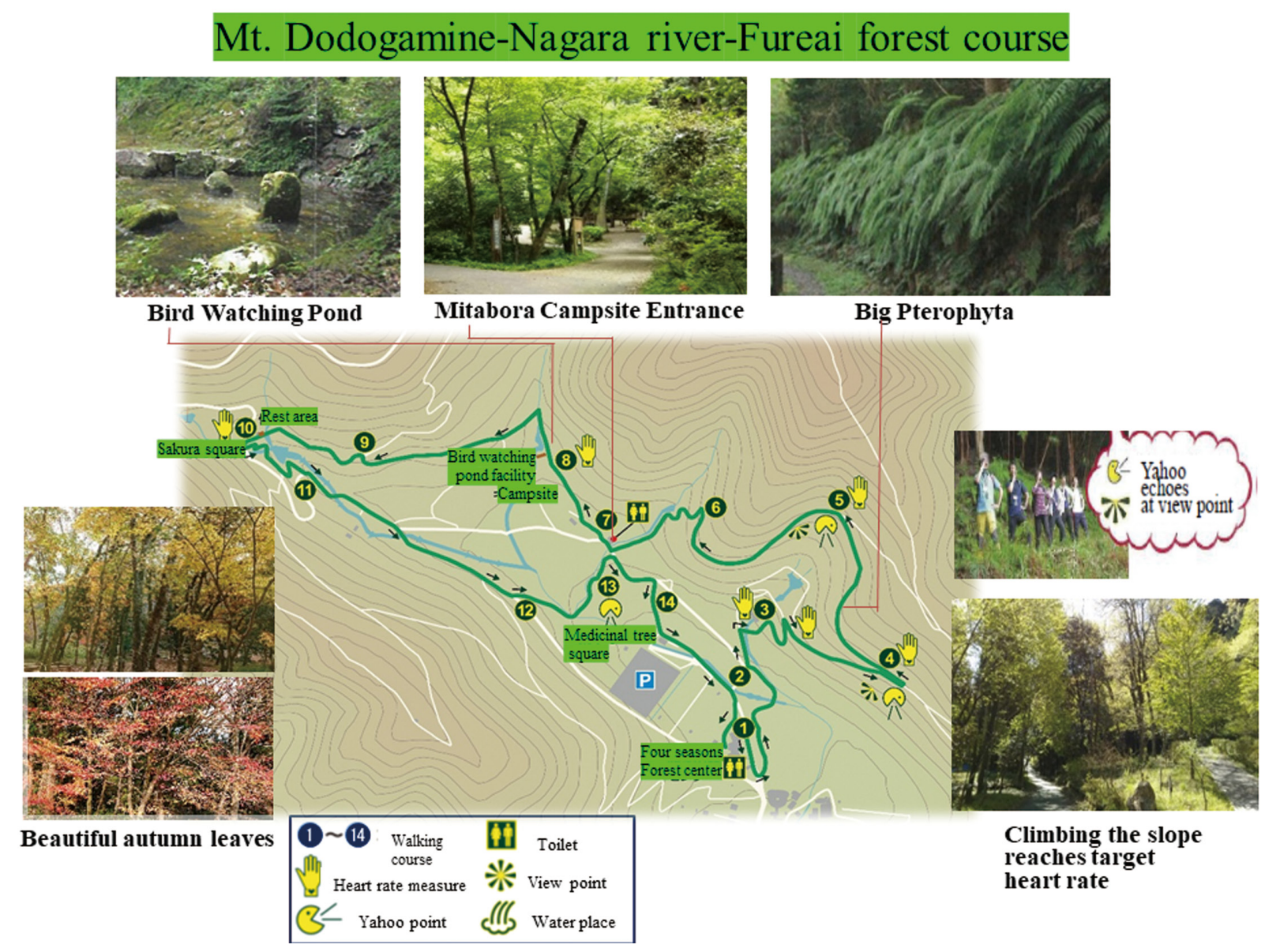

Figure 2. Mt. Dodogamine-Nagara River-Fureai Forest course. This course is situated in the northern area of the city in a beautiful forest with many seasonal birds. This course is $3.2 \mathrm{~km}$ long and has an elevation of $80 \mathrm{~m}$.

\section{Measurement of SBP, DBP, and Heart Rate}

SBP, DBP, and heart rate were measured before and after the completion of kurort health walking using a wrist-type sphygmomanometer. In analyses, SBP and DBP were each divided into 2 groups (SBP $\geq 140$ and $<140 \mathrm{mmHg}$; DBP $\geq 90$ and $<90 \mathrm{mmHg}$ group) based on the definition of hypertension in the 2019 Japanese Society of Hypertension guidelines for the management of hypertension. ${ }^{6}$

Heart rate was only evaluated for the 403 participants who documented their heart rate both before and after kurort health walking in the checklist.

\section{Measurement of Mood}

Based on a previously reported method, ${ }^{7}$ a questionnaire was used in this study to determine changes in the following 10 mood items: feeling lively, feeling refreshed, a vivid feeling, feeling exhilarated, feeling relaxed, feeling calm, a fun feeling, feeling anxious, feeling irritated, and feeling tired after completing the kurort health walking. Participants rated each item as 'improved', 'no change', or 'worsened'. These ratings were scored as 1 for 'improved', 0 for 'no change', and -1 for 'worsened'. The effects of kurort health walking on each of the 10 mood items individually and the sum score for all 10 mood items were assessed by averaging scores across all 454 participants.

\section{Statistical Analysis}

Data are presented as the mean \pm SD. The KolmogorovSmirnov test was used to determine the normality of data distribution. The significance of the differences in variables between groups was determined by paired and unpaired Student's t-tests. Correlation coefficients between 2 variables were obtained by linear regression analysis. Two-sided $\mathrm{P}<0.05$ was considered significant, and $\mathrm{P}<0.01$ and $\mathrm{P}<0.001$ were considered highly significant. All statistical analyses were performed using GraphPad Prism 7 (GraphPad Software, San Diego, CA, USA).

\section{Results}

\section{Participants' Background}

Of the 454 participants in this study, 136 were male and 318 were female. The age of participants ranged from 11 to 89 years (mean age $61.7 \pm 9.9$ years). Mean body mass index was $22.1 \pm 2.8 \mathrm{~kg} / \mathrm{m}^{2}$. Some of participants $(\sim 30 \%)$ had past histories of hypertension $(n=84)$, diabetes $(n=22)$, and dyslipidemia $(\mathrm{n}=31)$. 
A

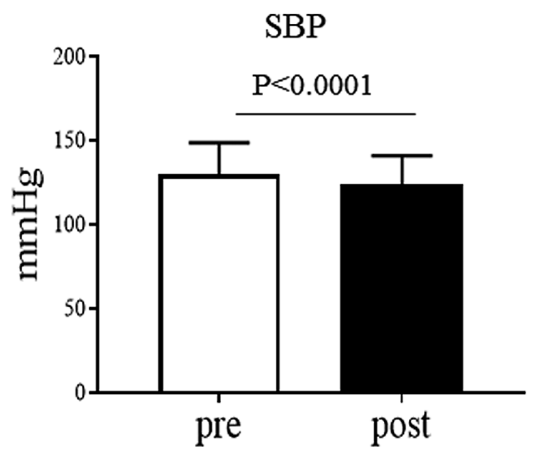

B

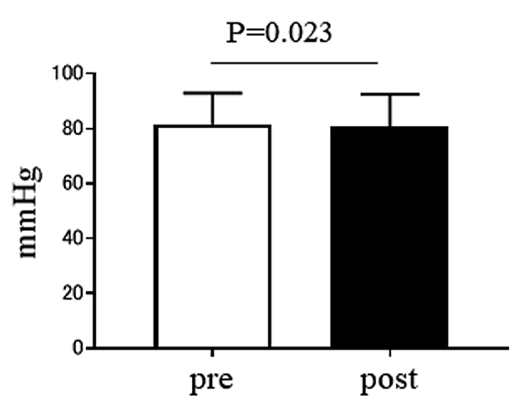

$\mathrm{C}$

HR

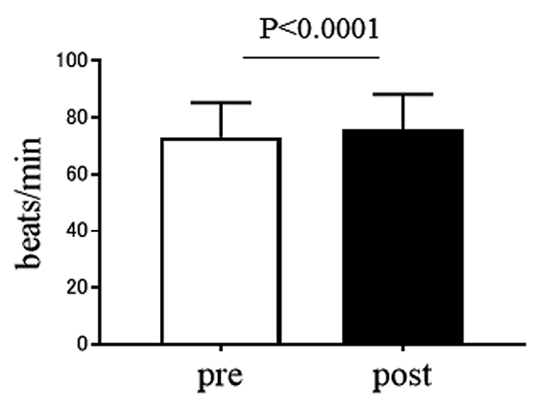

Figure 3. (A) Systolic blood pressure (SBP), (B) diastolic blood pressure (DBP), and (C) heart rate before (pre) and after (post) kurort health walking. Significant decreases were seen in (A) SBP (from 130.5 \pm 18.4 to $124.4 \pm 16.8 \mathrm{mmHg} ; n=454 ; P<0.0001$, paired Student's t-test) and (B) DBP (from 81.6 \pm 11.3 to $80.6 \pm 11.8 \mathrm{mmHg} ; \mathrm{n}=454 ; \mathrm{P}=0.0203$, paired Student's t-test), and $(\mathbf{C})$ heart rate increased significantly (from $73.1 \pm 12.1$ to $75.8 \pm 12$.3 beats $/ \mathrm{min} ; \mathrm{n}=415 ; \mathrm{P}<0.0001$, paired Student's t-test). Data are presented as the mean \pm SD.

\section{SBP, DBP, and Heart Rate}

Kurort health walking significantly decreased both SBP (from $130.5 \pm 18.4$ to $124.4 \pm 16.8 \mathrm{mmHg} ; \mathrm{P}<0.0001$; $\mathrm{n}=454$; Figure 3A) and DBP (from $81.6 \pm 11.3$ to $80.6 \pm 11.8 \mathrm{mmHg}$; $\mathrm{P}=0.0203 ; \mathrm{n}=454$; Figure 3B). Heart rate increased significantly from $73.1 \pm 12.1$ to $75.8 \pm 12.3$ beats $/ \min (\mathrm{P}<0.0001$; $\mathrm{n}=415$; Figure 3C).

In the SBP $\geq 140 \mathrm{mmHg}$ group, SBP decreased significantly from $152.2 \pm 10.2$ to $139.1 \pm 14.6 \mathrm{mmHg}(\mathrm{P}<0.0001 ; \mathrm{n}=140$; Figure 4A), whereas in the SBP $<140 \mathrm{mmHg}$ group SBP decreased significantly from $120.9 \pm 11.9$ to $117.8 \pm 13.2 \mathrm{mmHg}$ $(\mathrm{P}<0.0001 ; \mathrm{n}=314$; Figure 4B). The decrease in SBP was significantly greater in the SBP $\geq 140 \mathrm{mmHg}$ group $(-12.9 \pm 13.9 \mathrm{mmHg} ; \mathrm{n}=140)$ than in the $\mathrm{SBP}<140 \mathrm{mmHg}$ group $(-3.0 \pm 11.2 \mathrm{mmHg} ; \mathrm{n}=314 ; \mathrm{P}<0.0001$; Figure 4C). Thus, there was an inverse correlation between SBP before kurort health walking and the change in SBP after kurort health walking $(\mathrm{P}<0.0001$; Figure 4D).

In the DBP $\geq 90 \mathrm{mmHg}$ group, DBP decreased significantly from $96.1 \pm 5.6$ to $92.4 \pm 9.7 \mathrm{mmHg}(\mathrm{P}<0.0001 ; \mathrm{n}=112$; Figure 5A). In the DBP $<90 \mathrm{mmHg}$ group, DBP decreased from $76.8 \pm 8.2$ to $76.7 \pm 9.7 \mathrm{mmHg}(\mathrm{n}=342)$, but the difference did not reach statistical significance $(\mathrm{P}=0.823$; Figure 5B). The decrease in DBP was significantly greater in the DBP $\geq 90 \mathrm{mmHg}$ group $(-3.6 \pm 8.8 \mathrm{mmHg} ; n=112)$ than in the SBP $<90 \mathrm{mmHg}$ group $(-0.1 \pm 8.9 \mathrm{mmHg} ; \mathrm{n}=342 ; \mathrm{P}=0.0003$; Figure 5C). Thus, there was an inverse correlation between
DBP before kurort health walking and the change in DBP after kurort health walking $(\mathrm{P}<0.0001 ; \mathrm{n}=454$; Figure 5D).

\section{Mood}

Kurort health walking significantly improved scores for each of the mood items, namely feeling lively (mean score after walking $0.65 \pm 0.47 ; \mathrm{P}<0.0001$ compared with before walking), feeling refreshed $(0.87 \pm 0.33 ; \mathrm{P}<0.0001)$, a vivid feeling $(0.65 \pm 0.48 ; \mathrm{P}<0.0001)$, feeling exhilarated $(0.82 \pm 0.38$; $\mathrm{P}<0.0001)$, feeling relaxed $(0.77 \pm 0.41 ; \mathrm{P}<0.0001)$, feeling calm $(0.65 \pm 0.47 ; \mathrm{P}<0.0001)$, a fun feeling $(0.74 \pm 0.43$; $\mathrm{P}<0.0001)$, feeling anxious $(0.44 \pm 0.49 ; \mathrm{P}<0.0001)$, feeling irritated $(0.51 \pm 0.50 ; \mathrm{P}<0.0001)$, and feeling tired $(0.40 \pm 0.52 ; \mathrm{P}<0.0001)$. In addition, kurort health walking significantly improved the sum score of the 10 mood items (mean score after walking 6.5 \pm 3.2 out of perfect score of $10 ; \mathrm{P}<0.0001$ compared with before walking; Figure 6).

\section{Discussion}

The major findings of the present study are that: (1) kurort health walking in the courses in Gifu City decreased both SBP and DBP; (2) the decrease in SBP was significantly greater in the SBP $\geq 140$ than $<140 \mathrm{mmHg}$ group, and the change in SBP was inversely correlated with SBP before walking; (3) the decrease in DBP was significantly greater in the DBP $\geq 90$ than $<90 \mathrm{mmHg}$ group, and the change in 
A

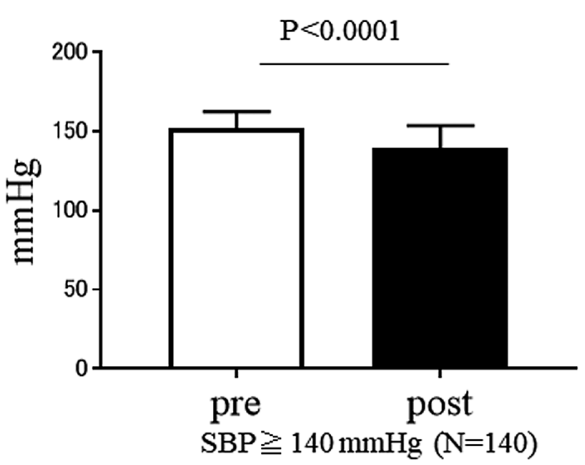

C

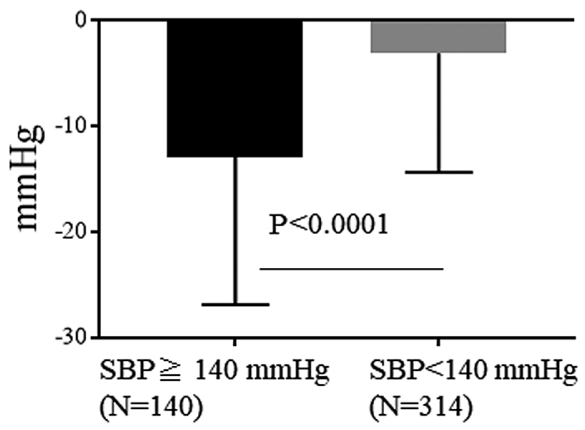

B

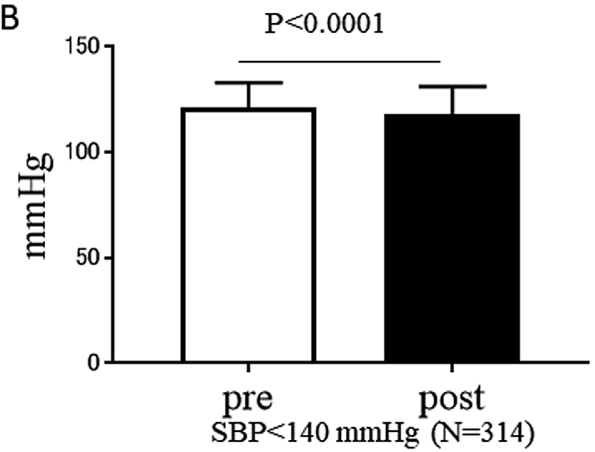

$D_{\triangle \mathrm{SBP}}$

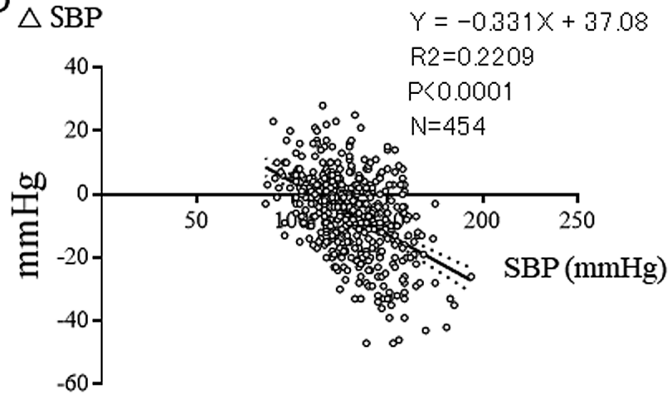

Figure 4. Kurort health walking-induced changes in systolic blood pressure (SBP) in participants according to SBP before kurort health walking ( $\geq 140$ vs. $<140 \mathrm{mmHg}$ ). (A) In participants with SBP $\geq 140 \mathrm{mmHg}$, kurort health walking significantly decreased SBP (152.2 \pm 10.2 to $139.1 \pm 14.6 \mathrm{mmHg} ; n=140 ; P<0.0001$, paired Student's t-test). (B) In participants with SBP $<140 \mathrm{mmHg}$, kurort health walking significantly decreased SBP (from $120.9 \pm 11.9$ to $117.8 \pm 13.2 \mathrm{mmHg} ; n=314 ; P<0.0001$, paired Student's t-test). (C) The decrease in SBP due to kurort health walking was significantly greater in the SBP $\geq 140$ than $<140 \mathrm{mmHg}$ group, with changes in $\operatorname{SBP}(\Delta \operatorname{SBP})$ of $-12.9 \pm 13.9 \mathrm{mmHg}(n=140)$ and $-3.0 \pm 11.2 \mathrm{mmHg}(n=314)$, respectively $(P<0.0001$, unpaired Student's t-test). Data are presented as the mean \pm SD. (D) Relationship between SBP and $\triangle$ SBP. There was an inverse correlation between SBP before kurort health walking and $\Delta \operatorname{SBP}(P<0.0001)$.

DBP was inversely correlated with DBP before walking; and (4) kurort health walking improved mood.

Recently in Japan, the popularity of kurort health walking has gradually increased with the support of local governments and companies. The 2 kurort health walking courses in Gifu City are well designed and well maintained by the Gifu City administration; thus, walking through these courses may improve participants' physical condition and mood by relieving physical and mental tension by attenuating augmented sympathetic nerve activity. In the present study, kurort health walking decreased SBP and DBP (Figure 3A,B) and significantly increased heart rate (Figure 3C). On average, kurort health walking decreased SBP by $6.1 \mathrm{mmHg}$, decreased DBP by $1 \mathrm{mmHg}$, and increased heart rate by 2.7 beats $/ \mathrm{min}$. The increase in heart rate after exercise such as walking is a physiologically normal response, and an increase in heart rate of 2.7 beats/min is very small and can be regarded as safe (Figure 3C). Checking participants' heart rate during kurort health walking to ensure that it was maintained under the target rate (calculated as [160-age] beats/min) meant that kurort health walking was performed safely.

When participants were divided into 2 groups based on SBP before kurort health walking (i.e., SBP $\geq 140$ and $<140 \mathrm{mmHg}$ ), the decrease in SBP after kurort health walk- ing was significantly greater in the SBP $\geq 140$ than $<140$ group $(-12.9 \pm 13.9$ vs. $-3.0 \pm 11.2 \mathrm{mmHg}$, respectively; $\mathrm{P}<0.0001)$, indicating that the higher the SBP, the greater the decrease in SBP after kurort health walking (Figure 4D). When participants were divided into 2 groups based on DBP before kurort health walking (i.e., DBP $\geq 90$ and $<90 \mathrm{mmHg}$ ), the decrease in DBP after kurort health walking was significantly greater in the DBP $\geq 90$ than $<90 \mathrm{mmHg}$ group $(-3.6 \pm 8.8$ vs. $-0.1 \pm 8.9 \mathrm{mmHg}$, respectively; $\mathrm{P}=0.0003$ ), indicating that the higher the $\mathrm{DBP}$, the greater the decrease in DBP (Figure 5D). Furthermore, as shown in Figures 4D and 5D, there is an inverse correlation between SBP and DBP before kurort health walking and the change in SBP and DBP after kurort health walking. Kurort health walking preferentially decreased higher than lower blood pressure and was safely performed even by hypertensive patients with SBP $\geq 140 \mathrm{mmHg}$ and DBP $\geq 90 \mathrm{mmHg}$, decreasing their high blood pressure (Figures 4,5). Based on these findings, kurort health walking may be a useful strategy to reduce SBP and DBP in hypertensive patients. It has previously been reported that aerobic exercise decreases both SBP and DBP in both hypertensive patients and normotensive subjects. ${ }^{8-11}$ The precise mechanisms by which aerobic exercise decreases blood pressure have not been fully clarified; however, some possible mech- 


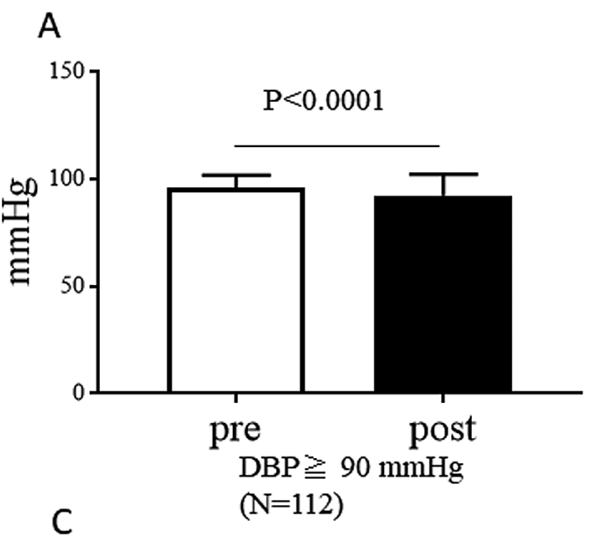

B
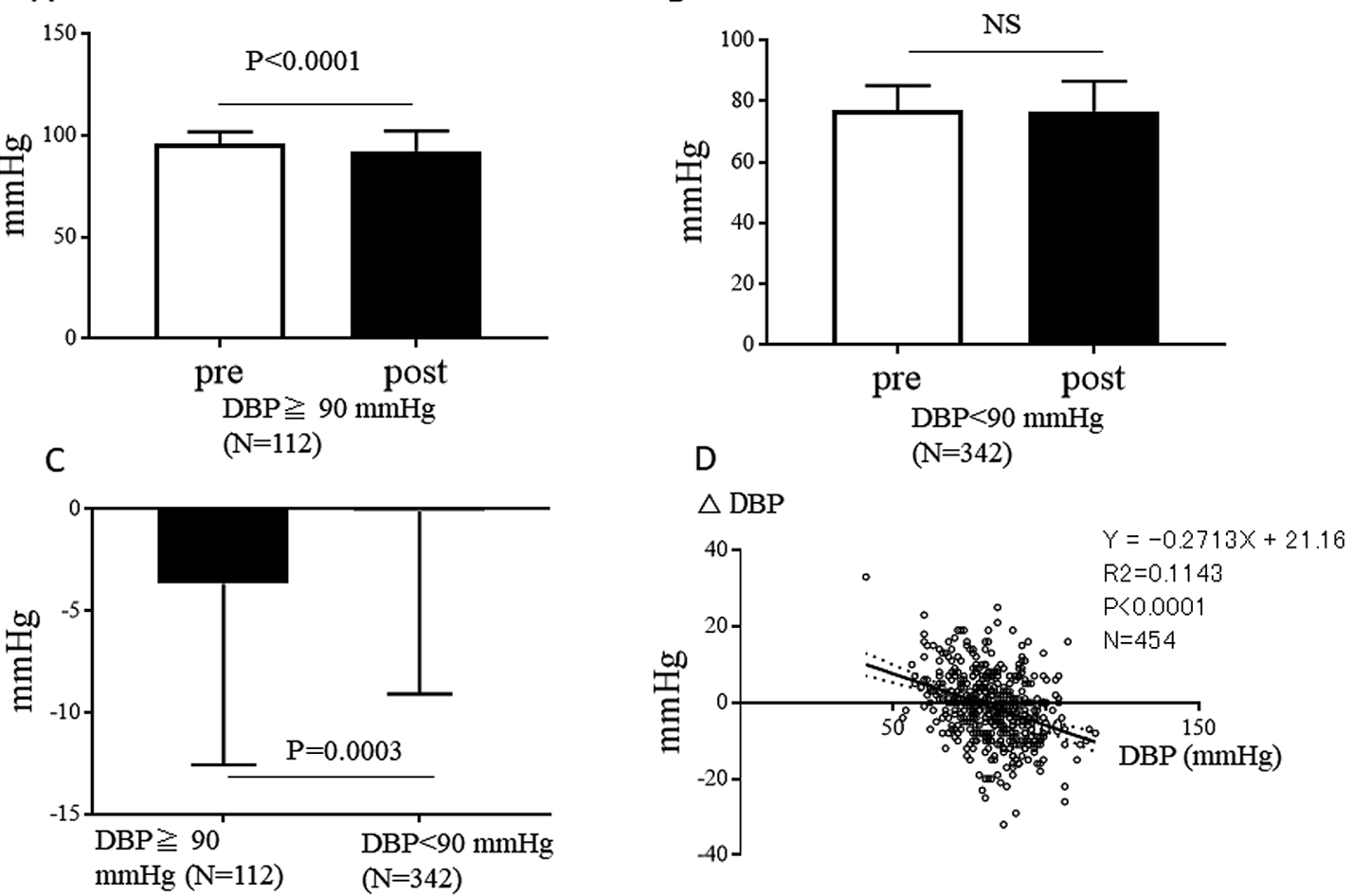

Figure 5. Kurort health walking-induced changes in diastolic blood pressure (DBP) in participants according to DBP before kurort health walking ( $\geq 90$ vs. $<90 \mathrm{mmHg}$ ). (A) In participants with DBP $\geq 90 \mathrm{mmHg}$, kurort health walking significantly decreased DBP (from 96.1 \pm 5.6 to $92.4 \pm 9.7 \mathrm{mmHg} ; \mathrm{n}=112 ; \mathrm{P}<0.0001$, paired Student's t-test). (B) In participants with $\mathrm{DBP}<90 \mathrm{mmHg}$, kurort health walking decreased DBP from $76.8 \pm 8.2$ to $76.7 \pm 9.7 \mathrm{mmHg}(n=342)$, but the difference did not reach statistical significance ( $P=0.823$, paired Student's t-test). (C) The decrease in DBP due to kurort health walking was significantly greater in the DBP $\geq 90$ than $<90 \mathrm{mmHg}$ group, with changes in DBP $(\triangle \mathrm{DBP})$ of $-3.6 \pm 8.8 \mathrm{mmHg}(n=112)$ and $-0.1 \pm 8.9 \mathrm{mmHg}(n=342)$, respectively $(P=0.0003$, unpaired Student's t-test). Data are presented as the mean $\pm S D$. (D) Relationship between DBP and $\triangle D B P$. There was an inverse correlation between DBP before kurort health walking and $\triangle \mathrm{DBP}(\mathrm{P}<0.0001 ; n=454)$.

anisms have been suggested, including attenuation of plasma norepinephrine and epinephrine concentrations and enhancement of plasma prostaglandin E concentrations by aerobic exercise. ${ }^{8}$

Kurort health walking also improved all 10 mood items (Figure 6). Of the 10 items evaluated, scores for feeling refreshed $(0.87 \pm 0.33)$, feeling exhilarated $(0.82 \pm 0.38)$, feeling relaxed $(0.77 \pm 0.41)$, and a fun feeling $(0.74 \pm 0.43)$ were higher, suggesting that these 4 feelings were greatly improved by kurort health walking. Furthermore, the sum of all 10 mood items was 6.5 \pm 3.2 (out of perfect score of 10); hence, more than $65 \%$ of participants showed an improvement in the sum of all 10 mood items following kurort health walking. These results suggest that kurort health walking may relieve mental tension and bring about an improvement in mood. Based on these results, kurort health walking may be a therapeutic strategy for improving mental health status. Previous studies found that aerobic exercise improved mental health status in patients with diabetes and depressive disorders, ${ }^{12,13}$ and others have reported that people who do not walk outside their home show more depressive symptoms or a greater likelihood of clinical depression. ${ }^{14}$ These reports may explain the beneficial effect of the kurort health walking in Gifu City, which consisted of walking outdoors, on mental health status. Because hypertension and mental health status have been reported to be associated with cardiovascular events, ${ }^{1-3}$ kurort health walking may be effective in reducing the risk of cardiovascular events because it decreases SBP and DBP and improves mood.

The advantages of kurort walking in Gifu City compared with normal walking may be that: (1) participants can walk in areas rich in nature, such as scenic hills, forests, rivers, and hot springs, and in a good climate, ${ }^{3}$ resulting in good mental feelings; (2) participants are accompanied by 2 health exercise instructors who provide appropriate advice during the walk; (3) blood pressure is measured before and after walking; and (4) heart rate during walking is maintained below the target rate, defined as (160-age) beats/min, by checking heart rate at various points over the course to ensure safety (Figures 1,2).

\section{Study Limitations}

This study only showed the short-term effects of a single bout of exercise. The long-term effects of kurort health walking on blood pressure and mood remain to be investigated. Because the participants in the kurort health walking program are general citizens of Gifu City who happened to take part in the program, we only recorded whether they had hypertension, diabetes, and dyslipidemia, which are 


\section{Effect of kurort health walking on changes in mental feelings}
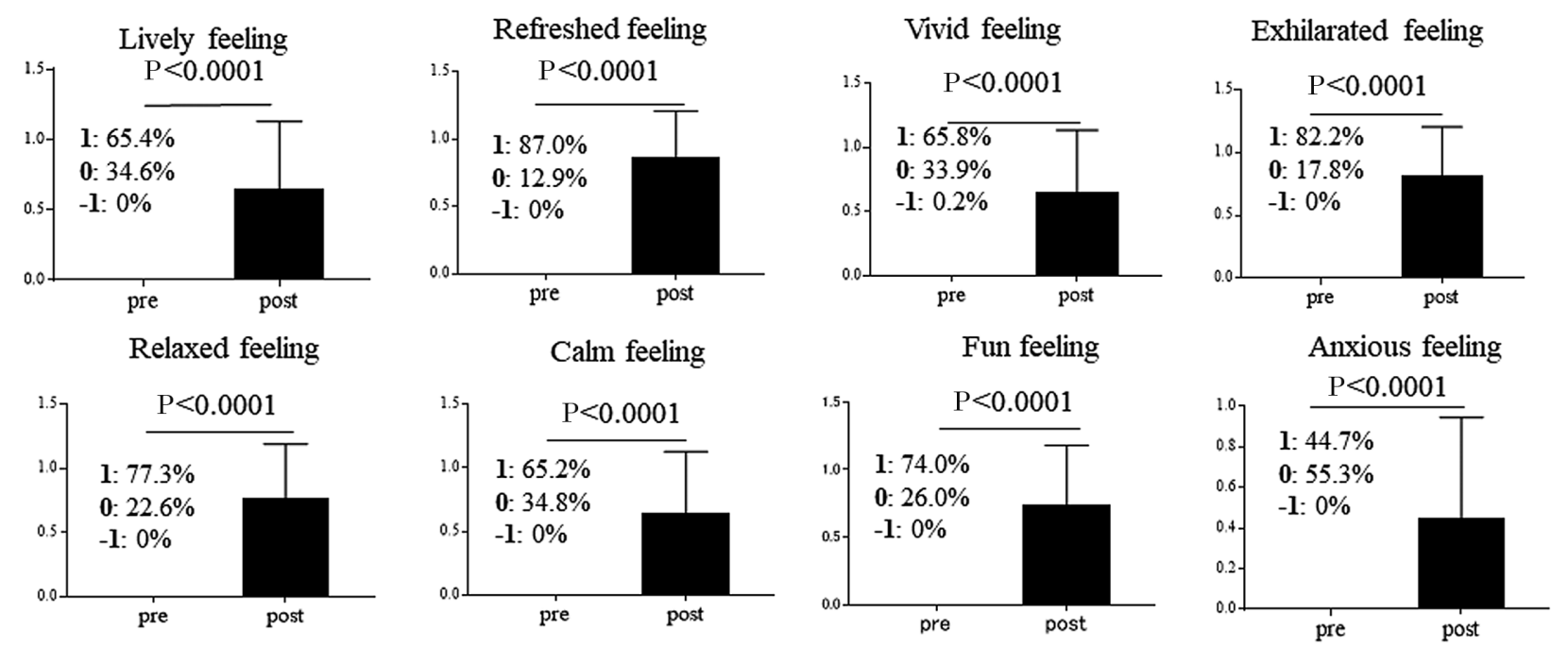

Irritated feeling
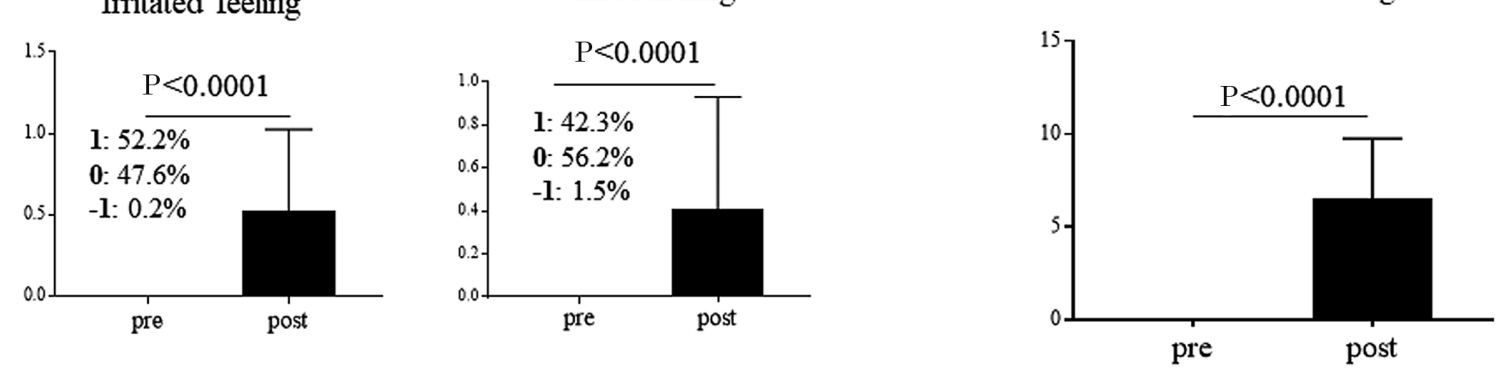

Figure 6. Effects of kurort health walking on changes in mood. Improvements were seen in all 10 mood items evaluated on the checklist after kurort health walking. Changes in mood items after kurort health walking were rated as improved (score $=1$ ), no change $($ score $=0)$, or worsened $($ score $=-1)$. For each item, the mean $\pm S D$ scores before and after kurort health walking are shown, with percentages for each category (1, improved; 0 , no change; -1 , worsened) across all 454 participants also presented. Changes in mood items from before to after kurort health walking were assessed by paired Student's t-test.

risk factors for coronary artery disease, on the checklist and did not obtain information regarding a history of cardiac and pulmonary diseases or drugs used. Furthermore, it is quite difficult to take blood samples from citizens who take part in kurort walking in the outdoors, although a survey based on blood data, such as blood glucose level, $\mathrm{HbA1c}$, and cholesterol concentrations, may be important. However, because kurort health walking can be regarded as a type of outdoor cardiac rehabilitation, information regarding a history of cardiac disease should have been obtained.

\section{Clinical Perspectives}

In this study, SBP and DBP decreased and mood improved in subjects who participated in the kurort health walking program in Gifu City. Of all the participants, approximately $30 \%$ had a history of hypertension, diabetes, and dyslipidemia, which are risk factors for coronary artery disease..$^{15}$ Even in these participants, kurort health walking was performed safely. The present study was performed between June 1, 2020 and May 30, 2021, during the coro- navirus pandemic, suggesting that because kurort health walking is mostly an outdoor activity, it can be safely performed in the coronavirus era.

In addition to effectively decreasing blood pressure and improving mood, kurort health walking could be an alternative tool for cardiac rehabilitation. Because cardiac rehabilitation has recently been reported to improve the prognosis of cardiac diseases such as acute myocardial infarction and heart failure, ${ }^{\mathbf{1 6}, 17}$ cardiac rehabilitation is recommended for these patients in the guidelines from the Japanese Circulation Society ${ }^{\mathbf{1 8}}$ and as part of the standard cardiac rehabilitation program for heart failure from the Japanese Association of Cardiac Rehabilitation Standard Cardiac Rehabilitation Program Planning Committee. ${ }^{19}$ However, under the health insurance system in Japan, cardiac rehabilitation is limited to 20 weeks after the onset of cardiac diseases. Thus, kurort health walking may be a suitable option for maintaining the health of cardiac patients after they have completed 20 weeks of cardiac rehabilitation. Further investigations are warranted. 


\section{Acknowledgment}

The authors are grateful for the support of the Health Promotion Section of Gifu Municipal Office, Gifu City, Japan.

\section{Sources of Funding}

This study was funded from the Sugiura Memorial Foundation, Obu City, Aichi, Japan.

\section{Author Contributions}

S.M.: organization and design of the study, data interpretation and analysis, manuscript writing, financial support, and final approval of manuscript. T.M., K.N., S.O., S.Y.: data collection and data interpretation, K.O.: data analysis, S.T., M.S., M.O., T.M.: organization of kurort health walking and data collection.

\section{Disclosures}

S.M. is a member of Circulation Reports' Editorial Team. The remaining authors have no conflicts of interest to disclose.

\section{IRB Information}

This study was approved by the Ethics Committee of Gifu Municipal Hospital (Approval no. 634).

\section{Data Availability}

The deidentified participant data will not be shared.

\section{References}

1. Stamler J, Stamler R, Neaton JD. Blood pressure, systolic and diastolic, and cardiovascular risks: US population data. Arch Intern Med 1993; 153: 598-615.

2. Nielsen TJ, Vestergaard M, Christensen B, Christensen KS, Larsen KK. Mental health status and risk of new cardiovascular events or death in patients with myocardial infarction: A population-based cohort study. BMJ Open 2013; 3: e003045.

3. Hata J, Kiyohara Y. Epidemiology of stroke and coronary artery disease in Asia. Circ J 2013; 77: 1923-1932.

4. Guenther K. Exercises in therapy: Neurological gymnastics between Kurort and hospital medicine, 1880-1945. Bull Hist Med 2014; 88: 102-131.

5. Wasserman K, Whipp BJ, Koyl SN, Beaver WL. Anaerobic threshold and respiratory gas exchange during exercise. $J$ Appl
Physiol 1973; 35: 236-243.

6. Umemura S, Arima H, Arima S, Asayama K, Dohi Y, Hirooka $\mathrm{Y}$, et al. The Japanese Society of Hypertension guidelines for the management of hypertension (JSH 2019). Hypertens Res 2019; 42: $1235-1481$.

7. Ueda H, Machida K, Kawamura N, Koseki N. A study on the process of mood alteration through forest walking. Journal of The Japanese Institute of Landscape Architecture 2013; 76: 533 538.

8. Kiyonaga A, Arakawa K, Tanaka H, Shindo M. Blood pressure and hormonal responses to aerobic exercise. Hypertension 1985; 7: $125-131$

9. Ghadieh AS, Saab B. Evidence for exercise training in the management of hypertension in adults. Can Fam Physician 2015; 61: 233-239.

10. Carpio-Rivera E, Moncada-Jiménez J, Salazar-Rojas W, SoleraHerrera A. Acute effects of exercise on blood pressure: A metaanalytic investigation. Arq Bras Cardiol 2016; 106: 422-433.

11. Whelton SP, Chin A, Xin X, He J. Effect of aerobic exercise on blood pressure: A meta-analysis of randomized, controlled trials. Ann Intern Med 2002; 136: 493-503.

12. Gilani SRM, Feizabad AK. The effects of aerobic exercise training on mental health and self-esteem of type 2 diabetes mellitus patients. Health Psychol Res 2019; 7: 6576.

13. Morres ID, Hatzigeorgiadis A, Stathi A, Comoutos N, ArpinCribbie C, Krommidas C, et al. Aerobic exercise for adult patients with major depressive disorder in mental health services: A systematic review and meta-analysis. Depress Anxiety 2019; 36: $39-53$

14. Julien D, Gauvin L, Richard L, Kestens Y, Payette H. The role of social participation and walking in depression among older adults: Results from the VoisiNuAge study. Can J Aging 2013; 32: $1-12$.

15. Kannel WB. Some lessons in cardiovascular epidemiology from Framingham. Am J Cardiol 1976; 37: 269-282.

16. Witt BJ, Jacobsen SJ, Weston SA, Killian JM, Meverden RA, Allison TG, et al. Cardiac rehabilitation after myocardial infarction in the community. $J$ Am Coll Cardiol 2004; 44: 988-996.

17. O'Connor CM, Whellan DJ, Lee KL, Keteyian SJ, Cooper LS, Ellis SJ, et al. Efficacy and safety of exercise training in patients with chronic heart failure: HF-ACTION randomized controlled trial. JAMA 2009; 301: 1439-1450.

18. JCS Joint Working Group. Guidelines for rehabilitation in patients with cardiovascular disease (JCS 2012): Digest version. Circ J 2014; 78: 2022-2093.

19. Izawa $\mathrm{H}$, Yoshida $\mathrm{T}$, Ikegame $\mathrm{T}$, Izawa $\mathrm{K}$, Ito $\mathrm{Y}$, Okamura $\mathrm{H}$, et al. Standard cardiac rehabilitation program for heart failure. Circ J 2019; 83: 2394-2398. 